Manuscript received: 07.10.2020

Accepted: 08.03.2021

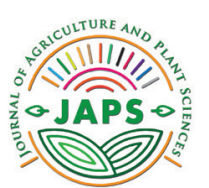

In print: ISSN $2545-4447$

On line: ISSN 2545-4455

https://doi.org/10.46763/JAPS211910018b

Original scientific paper

\title{
WATER PRODUCTIVITY AND EFFICIENCY IN VIOLATED MAIZE IRRIGATION REGIME FOR SILAGE MAIN CULTURE
}

\author{
Rumen Bazitov ${ }^{1 *}$ \\ 'Agricultural Institute, 6000 Stara Zagora, Bulgaria \\ *Corresponding author: rumen7588@abv.bg
}

\begin{abstract}
In the experimental field of the Agricultural Institute, Stara Zagora, on meadow - cinnamon type soil, an experiment with a medium - late maize hybrid Antalya 450 from FAO in case of disturbed irrigation regime was conducted. It was found that the optimally irrigated variant with three irrigations yields an average yield of $1607 \mathrm{~kg} / \mathrm{dry}$ biomass, which is $20.0 \%$ higher than the yield obtained from the non-irrigation variant. With the cancellation of the second irrigation the yield of dry mass decreases by $7.6 \%$ compared to the optimal variant, and with the cancellation of the first irrigation the losses of dry biomass reach respectively $12.3 \%$ compared to the control variant. The effect of the application of disturbed irrigation regime is highest when canceling the first watering irrigation $(K=0.93)$ and the lowest values are for the variant with cancellation of the second irrigation $(K=0.57)$.
\end{abstract}

Keywords: maize, irrigation, productivity, dry biomass

\section{INTRODUCTION}

The great potential of corn for high yields, the high energy value of the feed obtained from it, and its easy preservation by silage impose it as a major source of bulky feed for ruminants (Stoycheva, I., 2015). studies for growing corn, with optimal and insufficient security, but they are mainly for grain production (Matev, 2001; Matev et al., 2013; Kalaydzieva and Matev 2011; 2012; Georgieva et al., 2014; Glogova and Nankov, 2006; Stoyanova, 2007; 2009). A number of studies have been conducted with corn for silage under irrigated conditions, but mainly to study the various agrotechnical factors on its productivity (Videva,et al.,1993; Kertikova and Kertikov, 2011;). There is little and insufficient research in connection with the cultivation of silage corn in the conditions of water deficit, which in the coming years will increasingly accompany the cultivation of corn in our country. The aim of the present study is to establish the productivity and efficiency of water in case of disturbed irrigation regime of maize for silage grown as a main crop.

\section{MATERIAL AND METHODS}

The study was conducted in the period 2014 - 2016 in the experimental field of the Agricultural Institute, Stara Zagora on meadow - cinnamon soil with medium-late maize hybrid Antalya 450 from FAO. The soil in the experimental field is characterized by the following water - physical properties: FC - 26.57\%, coefficient of wilting (KZ) - 18.19\%, porosity $-47 \%$ and bulk density -1.45 . The tillage and sowing of corn for silage were carried out in the optimal agro-technical term for the region. The application of nitrogen fertilizer was carried out in phase 3 - 5 leaf of the culture. During the vegetation we fought against annual and perennial weeds with the herbicides Mistral Opti 240SK in a dose of $21 \mathrm{ml} / \mathrm{da}$ and Casper 
$55 \mathrm{VG}$ in a dose of $30 \mathrm{~g} / \mathrm{da}$ applied in the culture phase of 3-5 leaves. During the vegetation we performed manual hoeing and shaping of the furrows for irrigation. The study includes the following variants of disturbed irrigation regime: lime.1 Without irrigation - control, lime. 2 Optimal irrigation by three watering cans.3
Irrigation as lime. 2, but with the abolition of the first irrigation.4 Irrigation as lime.2, but with the abolition of the second irrigation.5 Irrigation as lime.2, but with the abolition of the third irrigation. Mathematical processing of the data was performed by software product ANOVA.

\section{RESULTS AND DISCUSSION}

The productivity of maize for silage depends both on the agro-technical measures and on the meteorological conditions of the years. Of essential importance for maize is the amount of precipitation that fell during the months of active vegetation (VI - VIII). Figure 1 shows the sum of precipitation by months, years and total for the study period. In terms of rainfall, the months of June and July 2014, which have a significant contribution to the formation of maize yields, are characterized as moderately wet, and August is a wet month, with $P \&, 47.2 \%, 33 \%$ and $2 \%$, respectively, For 2015 the provision of precipitation for the months of June, July and August is P - 4.7\%, $89.8 \%$ and $62.4 \%$, ie June is humid, July is dry, and August is an average dry month. For 2016, the month of June is covered by P - $50 \%$, for July - $95 \%$ and for August - 90.1\%, ie June is wet, and July and August - dry months. During the three experimental years the amount of precipitation was unevenly distributed. Most precipitation in the period May-September fell in 2014 - 385.9 $\mathrm{mm}$ and compared to the same months of the multi-year period this amount is higher by 134.2 $\mathrm{mm}$. In 2015, the amount of precipitation was $29.8 \mathrm{~mm}$ higher, and in $201618.4 \mathrm{~mm}$ lower than the average for the multi-year period.

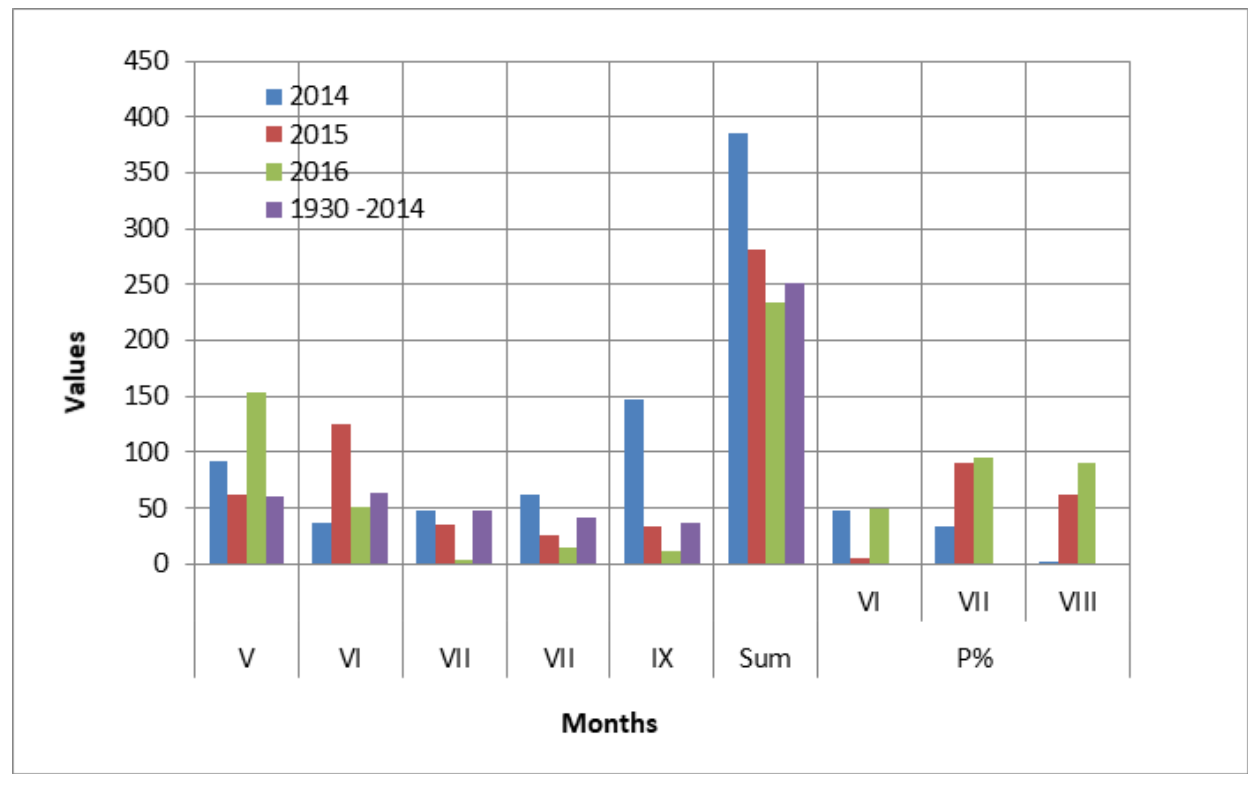

Figure 1. Sum of rains, $\mathrm{mm}$

The sum of the average daily air temperatures during the study years did not differ significantly from those of the multi-year period (Fig. 2) 


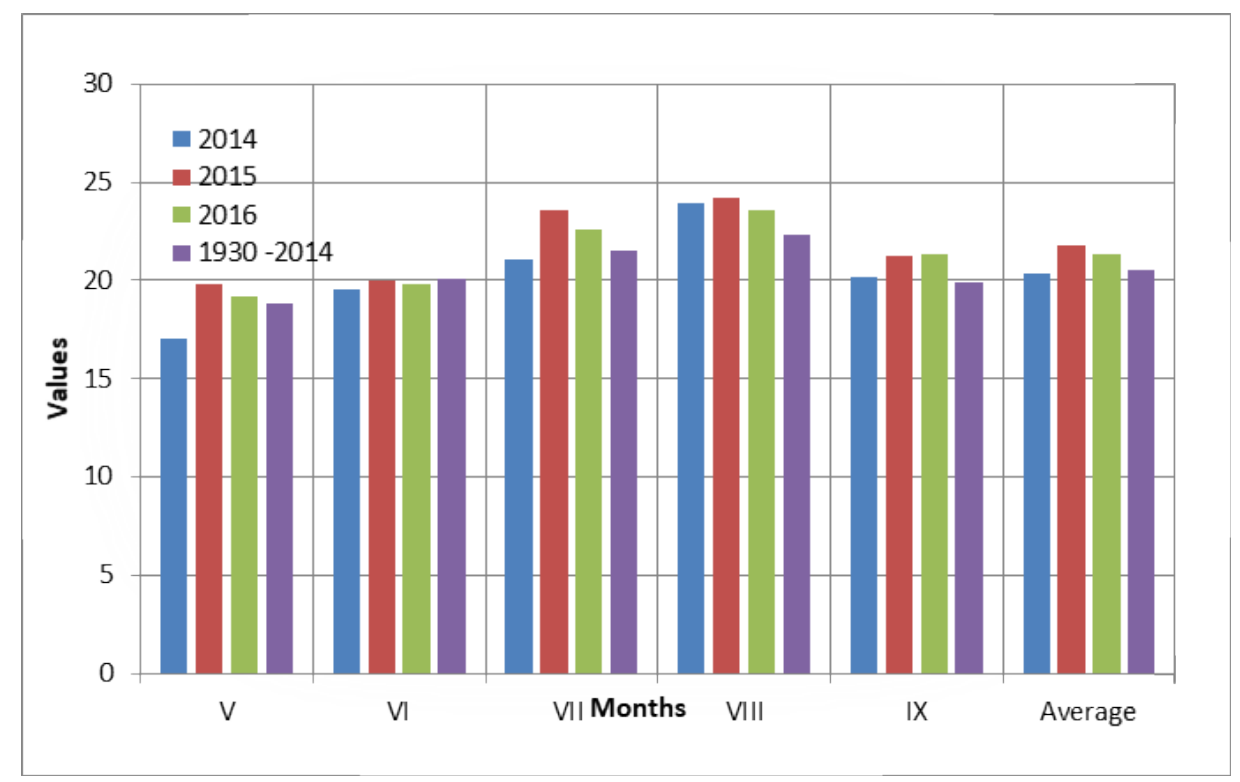

Figure 2 .Sum of the average daily temperature, ${ }^{\circ} \mathrm{C}$

In determining the effect of the application of the studied variants with the cancellation of irrigation, if it is proved necessary by changing the obtained yield of dry mass compared to the non-irrigated variant, it is established that in lime. 2 (optimal irrigation) the increase of the yield is $20.0 \%$ (Table 1 ) In the variants irrigated together with lime. 2, but with the abolition of irrigation, the largest increase in the amount of yield is observed in option 3 (with the abolition of the first irrigation) $-12.3 \%$. For the variants with cancellation of the second and third irrigation, respectively, the yield increases by 7.6 and $9.1 \%$, respectively, compared to the control variant.

When comparing the yields obtained in the individual variants with the yield obtained from the optimally irrigated variant, it is found that the weakest reduction of the yield from dry mass of corn is in the variant with cancellation of the first irrigation (var.3), respectively $6.4 \%$. In the variants with cancellation of the second and third irrigation (var.4 and var.5) the yield of dry mass decreased by $10.3 \%$ and $9.1 \%$, respectively. The strongest decrease in yield $-16.7 \%$ is observed when growing Sudan without irrigation.

When analyzing the productivity indicator per $1 \mathrm{~m}^{3}$ of irrigation water, it turns out that as the number of irrigations decreases, so does the productive use of water. On average for the vegetation period of corn from one cubic meter of water is obtained from 6.02 to $8.45 \mathrm{~kg} / \mathrm{da}$ dry biomass. The highest values of this indicator are obtained at lime 3 , respectively 8.45 dry biomass. In second place is the option with the abolition of the third watering - lime 5., respectively 8.21. When irrigating maize without a second irrigation (var. 4) the productivity of $1 \mathrm{~m} 3$ of irrigation water of the vessel reaches $8.10 \mathrm{~kg} /$ da dry biomass. Last in terms of productivity per $1 \mathrm{~m} 3$ of water is the optimally irrigated option 2 , in which $6.02 \mathrm{~kg}$ of dry mass is obtained from each cubic meter of water.

The efficiency of the application of the different irrigation regimes can be expressed by the indicator - coefficient of the irrigation norm $\mathrm{K}$, which represents the ratio between the increase of the yield (compared to the variant without irrigation) and the size of the realized irrigation norm. In case of variation with cancellation of the first watering $\mathrm{K}$ is 0.93 , i.e. each cubic meter of water provided an additional yield of dry biomass of $930 \mathrm{~g}$.

In the case of optimally irrigated variant 2 , the values of the efficiency coefficient of the irrigation norm are 1.00. In case of cancellation irrigation, respectively of the second and third irrigation, the values of the coefficient are 0.57 and 0.69 , respectively. each cubic meter of water provided an additional yield of $570 \mathrm{~g}$ dry biomass when canceling the second irrigation and $690 \mathrm{~g}$ dry biomass when canceling the third irrigation. 
Table 1. Efficiency and productivity of irrigation water for 2014 - 2016

\begin{tabular}{|c|c|c|c|c|c|c|c|}
\hline Variants & $\begin{array}{l}\mathrm{M} \mathrm{m}^{3} / \\
\mathrm{da}\end{array}$ & 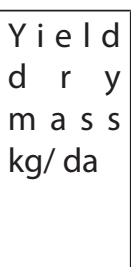 & $\begin{array}{l}+/-y \text { i eld } \\
\text { k g / d a } \\
\text { compared } \\
\text { to var. } 1\end{array}$ & $\begin{array}{l}\text { +/- yield in } \\
\text { \% compared } \\
\text { to var. } 1\end{array}$ & $\begin{array}{l}+/- \text { yield in } \\
\% \text { compared } \\
\text { var. } 2\end{array}$ & $\begin{array}{l}\text { Productivity } \\
\text { of } 1 \mathrm{~m}^{3} \text { water } \\
\text { in } \mathrm{kg} / \mathrm{m}^{3}\end{array}$ & $\begin{array}{l}\text { Coefficient of } \\
\text { efficiency of } \\
\text { the irrigation } \\
\text { norm } \\
\text { (K). }\end{array}$ \\
\hline $\begin{array}{l}\text { 1.Without irrigation } \\
\text { (control) }\end{array}$ & - & 1339 & - & 100 & 83,3 & - & - \\
\hline $\begin{array}{l}\text { 2.Optimalirrigation } \\
\text { - three watering }\end{array}$ & 267 & 1607 & 268 & 120.0 & 100 & 6.02 & 1.00 \\
\hline $\begin{array}{l}\text { 3. With the abolition } \\
\text { of the I watering }\end{array}$ & 178 & 1505 & 166 & 112,3 & 93.6 & 8.45 & 0.93 \\
\hline $\begin{array}{l}\text { 4.With the abolition } \\
\text { of the II watering }\end{array}$ & 178 & 1442 & 103 & 107.6 & 89.7 & 8.10 & 0.57 \\
\hline $\begin{array}{l}\text { 5. With the abolition } \\
\text { of the III watering }\end{array}$ & 178 & 1462 & 123 & 109.1 & 90.9 & 8.21 & 0.69 \\
\hline $\begin{array}{l}\text { Great differences } \\
\text { (GD) \% 5\%- } 3.791 \\
; 1 \%-5.182 ; 0.1 \%- \\
7.038 \mathrm{~kg} / \mathrm{da}\end{array}$ & & & & & & & \\
\hline
\end{tabular}

\section{CONCLUDING REMARKS}

During the study period 2014 - 2016, the optimally irrigated variant with three irrigations yielded an average yield of $1607 \mathrm{~kg} / \mathrm{da}$ dry mass, which is $20.0 \%$ higher than the yield obtained from the variant without irrigation.

With the cancellation of the second irrigation the dry mass yield decreases by $7.6 \%$ compared to the optimal variant, and with the cancellation of the first irrigation the losses of dry biomass reach respectively $12.3 \%$ compared to the control variant.
The productivity of one cubic meter of irrigation water in the optimally irrigated variant is $6.02 \mathrm{~kg} / \mathrm{m} 3$. The highest values of this indicator are obtained for the variant with cancellation of the first irrigation $-8.45 \mathrm{~kg} / \mathrm{m}^{3}$

The effect of the application of disturbed irrigation regime is highest in the cancellation of the first irrigation $(K=0.93)$, and with the lowest values is in the variant with cancellation of the second irrigation $(\mathrm{K}=0)$.

\section{REFERENCES}

Georgieva, I., Nankov, M., \& Hristova, S. ( 2014). Influence of the periodical water deficit

on the productivity of maize grain. Plant sciences, vol. LI (2-3), 92-96.

Glogova, L.,\&Nankov, M. (2006). Determining the total productivity of corn for grain depending on the processing and fertilization. Sixth International Symposium "Ecology - Sustainable Development": Scientific Papers/, Vratsa, 19-21.10, pp. 45-49. http:// unicat.nalis.bg/Record/NBU.49791581

Kalaydzieva, R., \& Matev, A. (2011). The irrigation rate influence on the productivity of corn for grain. Journal of Mountain of the Balkans,14 (6), 1266 - 1277.

Kalaydzieva, R., \& Matev, A. (2012). Impact of periodical water deficit on the productivity of grain corn in district of Plovdiv. Science and technologies, 2(6), 127 - 131.

Kertikova, D., \& Kertikov, T. (2011). Study of the economic qualities of maize hybrids from the middle-late and late FAO group. II. Suitability of hybrids for biomass production silage. Agricultural Science,44 (5), 35 - 42. 
Matev, A. (2001). Influence of the periodic water deficit on the grain yield of corn. Plant sciences,38(5-6), $224-228$.

Matev, A, Petrova, R., \& Kirchev, H. (2013). Impact of Irrigation Regime on the Yield Components of maize for grain. Conference: Proceedings of the University of Ruse, 52 (1.1), 36-45

Stoyanova, A. (2007). Maize productivity for grain irrigation through furrows. Proceedings of the International Scientific Conference, June 7 -
8, Stara Zagora, Vol. I,158 - 162.

Stoyanova, A. (2009). Irrigation regime of grain maize. Bulgarian Journal of Agricultural Science, 15 (6), 528-532.

Stoycheva, I. (2015). Influence of grazing and preserved forage on milk production of sheep. PhD These, Pleven, Bulgaria

Videva, M., Hristozov, A., Pavlov D., Zhelyazkova, Ts.,\& Eneva, S. (1993). Productivity and structure of yield of maize hybrids for silage, Plant Sciences,30( 1 -4), 149-152.

\title{
ПРОДУКТИВНОСТ И ЕФИКАСНОСТ ВО НАРУШЕН РЕЖИМ НА НАВОДНУВАҢЕ НА ПЧЕНКА ЗА СИЛАЖА КАКО ГЛАВНА КУЛТУРА
}

\author{
Румен Базитов ${ }^{1 *}$ \\ 'Земјоделски институт, 6000 Cтара Загора, Бугарија \\ *Контакт-автор: rumen7588@abv.bg
}

\section{Резиме}

Во експерименталното поле на Земјоделскиот институт, Стара Загора, на почва од типот на ливада - цимет, беше спроведен експеримент со средно-доцната хибридна пченка анталија 450 од ФАО со нарушен режим на наводнување. Откриено е дека оптимално наводнуваната варијанта со три наводнувања дава просечен принос од $1607 \mathrm{~kg} /$ сува биомаса, што е за 20,0\% поголем од приносот добиен од варијантата без наводнување. Со откажувањето на второто наводнување, приносот на сува маса се намалува за 7,6\% во споредба со оптималната варијанта, а со откажувањето на првото наводнување загубите на сувата биомаса достигнуваат соодветно $12,3 \%$ во споредба со контролната варијанта. Ефектот од примената на нарушен режим за наводнување е најголем при откажување на првото наводнување за наводнување $(K=0,93)$, а најниските вредности се за варијантата со откажување на второто наводнување $(\mathrm{K}=0,57)$

Клучни зборови: пченка, наводнување, продуктивност, сува биомаса. 